\section{Problems in Hungary}

\section{London}

HuNGARY's uranium industry is in trouble. Closure of the country's only uranium mine, in the Mecsek hills, is virtually inevitable, according to industry minister Ferenc Horvath, although the government will not reach a final decision until September.

Under an agreement with the Soviet Union dating from the mid-1950s, the Hungarian government is now allowed to publish details of its uranium production, but it is no secret that the mine is uneconomic. Annual government subsidies to uranium mining have almost doubled since 1985 and this year amount to 2,500 million forints ( $\$ 40$ million). According to the Hungarian economic journal Világgazdaság, if the mine remains open, this subsidy could reach 5,000 million forints by the mid-1990s.

Under the existing agreement, all Hungarian uranium ore has to be delivered to the Soviet Union which supplies fuel elements to Hungary for the 1760-MW nuclear power station at Paks. The intraComecon pricing system is based on world market prices averaged over the past five years.

With the current depressed state of the uranium market, the Soviet Union, says Világgazdaság, is now paying considerably more than the free market price for yellowcake $(\$ 60-70$ as against $\$ 40-45$ a kilogram). Furthermore, the Soviet Union allocates to Hungary interest-free loans for geological surveys and also supplies goods - including timber and chemicals - related to the uranium industry.

The Paks power station itself runs at an ELECTIONS

\section{Success for Greens}

\section{Sydney}

THE Greens won their first big victory in Australia last month when they joined a coalition with the Labor party to take power in Tasmania.

The Liberal party won the largest number of seats in the elections in May but with 17 seats were one short of an absolute majority. At the end of June they lost a no-confidence vote, allowing the Labor party, with 13 seats, and the Green Independents, with five seats, to form a coalition government.

The accord between the two parties limits the state's woodchip quota, creates new parks, adds to the list of proposed world heritage sites, prohibits several forest product ventures and transforms the logging industry. Labor is being pushed by the Greens to introduce aboriginal freehold land rights, price controls, equal opportunity laws, four-year parliamentary terms, freedom of information laws and increased funding for education.

Tania Ewing apparent profit, contributing an annual 500 million forints to the state budget. But this is calculated on the basis of a generating cost of 1.10 forints per $\mathrm{kwh}$, of which the uranium costs a nominal 0.08 forints. Several months ago, the Paks management was worried about the subsidies to uranium mining being withdrawn and having to buy fuel elements at full production cost. Secrecy restrictions made it difficult for them to draw up contingency plans although, it was hinted, they did not rule out the possibility of buying their fuel elements from some source other than the Soviet Union in the future.

According to Gyula Czipper, the deputy industry minister, at the present rate of production, Hungary's uranium reserves would last at least another 30 years. The deposits, however, which lie at $800-1,000$ metres depth, seem likely to remain unprofitable. The management of the Mecsek mine has begun a survey to try to locate small deposits nearer the surface, which would be considerably cheaper to work, but this seems to be a last-ditch stand to stave off closure.

According to Világgazdaság, the mine management has now been authorized by the Hungarian government to seek a buyer on the world market, despite the agreement with the Soviet Union. And it now seems likely that the secrecy surrounding the Hungarian uranium industry will be lifted in the next few weeks. Vera Rich

\title{
Benveniste under review
}

\section{Parls}

DR Jacques Benveniste, whose research on the 'memory of water' put him (and Nature, which published his results) at the centre of international controversy last year, has been reprimanded by the French national institute of health and medical research (INSERM). While the reports of two evaluation committees were generally favourable towards the overall work of his laboratory, Unit 200, he has been given a six-month probationary period to re-

\section{IMAGE UNAVAILABLE FOR COPYRIGHT REASONS}

\section{Beneviste - claims for dilute water}

establish "the full guarantee of his peers".

The evaluation of laboratories is a standard four-yearly procedure within INSERM and was not provoked by the controversy surrounding Benveniste's research. But when the first review by a specialist pharmacology committee was carried out in April, there were already signs that his work on high dilutions would not be judged favourably. They "issued a statement asking me to stop work on high dilutions, without any scientific reasons", he told Nature. Benveniste protested, but said that he would be willing to obey. His research was then re-evaluated by INSERM's scientific council, which included two experts from foreign institutions.

On Monday of this week, Benveniste met INSERM director Phillipe Lazar to hear the final decision about his post as director of research and the future of his research unit. In a statement to the press, the INSERM directorate explained that the two evaluation committees shared a "very favourable opinion of the overall activities of the laboratory", but were "extremely reserved regarding the studies of high dilutions". The statement went on to criticize Benveniste for "an insufficiently critical analysis of the results he reported, the cavalier character of the interpretations he made of them, and the abusive use of his scientific authority vis-a-vis his informing of the public".

Benveniste's research unit of immunopharmacology of allergy and inflammation has been given approval to continue to 30 June 1992. Benveniste should also be allowed to stay as director of the unit when his present mandate expires at the end of the year. But this decision is suspended until 31 December "at the latest", during which time he is asked to adopt the "critical and reserved attitude" expected of a scientist.

Speaking to Nature before his interview with Lazar, Benveniste remained adamant that he has been unfairly treated and that Nature will end up looking foolish for having debunked his research. He pointed out that he has published 67 papers and major reviews in the past four years, of which two are "citation classics". $\mathrm{He}$ claimed that his research findings have now been independently confirmed and said that he is "flabbergasted at the risk" taken by Nature last year. "What if I am right?", he asked. For INSERM, the risks are the same.

Peter Coles 